\title{
Correction to: Can routine perioperative haemodynamic parameters predict postoperative morbidity after major surgery?
}

Jean-Francois Bonnet ${ }^{1 *+}$, Eleanor Buggy ${ }^{1 \dagger}$, Barbara Cusack ${ }^{1}$, Aislinn Sherwin ${ }^{1}$, Tom Wall $^{1}$, Maria Fitzgibbon $^{2}$ and Donal J. Buggy'

\section{Correction to: Perioper Med (2020) 9: 9 https://doi.org/10.1186/s13741-020-0139-6}

Following publication of the original article (Bonnet et al. 2020), the authors identified an error in the methods section.

In the Methods section, we stated that the patients studied in our single centre were already in the ongoing MET-Repair study: In fact, the patient cohort we described was a separate local group of patients with similar enrollment criteria to MET-Repair, but our outcome measures were entirely different as reported in our study.

\footnotetext{
Author details

'Department of Anaesthesiology \& Perioperative Medicine, Mater University Hospital, School of Medicine, University College Dublin, Dublin, Ireland. ${ }^{2}$ Department of Medical Biochemistry, Mater University Hospital, School of Medicine, University College Dublin, Dublin, Ireland.
}

Published online: 29 May 2020

\section{Reference}

Bonnet J, Buggy E, Cusack B, et al. Can routine perioperative haemodynamic parameters predict postoperative morbidity after major surgery? Perioper Med. 2020;9:9 https://doi.org/10.1186/s13741-020-0139-6.

The original article can be found online at https://doi.org/10.1186/s13741020-0139-6.

* Correspondence: jfbonnet@live.com

${ }^{\dagger}$ Jean-Francois Bonnet and Eleanor Buggy are joint first authors and contributed equally to this work

${ }^{1}$ Department of Anaesthesiology \& Perioperative Medicine, Mater University Hospital, School of Medicine, University College Dublin, Dublin, Ireland

Full list of author information is available at the end of the article

(c) The Author(s). 2020 Open Access This article is licensed under a Creative Commons Attribution 4.0 International License, which permits use, sharing, adaptation, distribution and reproduction in any medium or format, as long as you give appropriate credit to the original author(s) and the source, provide a link to the Creative Commons licence, and indicate if changes were made. The images or other third party material in this article are included in the article's Creative Commons licence, unless indicated otherwise in a credit line to the material. If material is not included in the article's Creative Commons licence and your intended use is not permitted by statutory regulation or exceeds the permitted use, you will need to obtain permission directly from the copyright holder. To view a copy of this licence, visit http://creativecommons.org/licenses/by/4.0/. The Creative Commons Public Domain Dedication waiver (http://creativecommons.org/publicdomain/zero/1.0/) applies to the data made available in this article, unless otherwise stated in a credit line to the data. 